
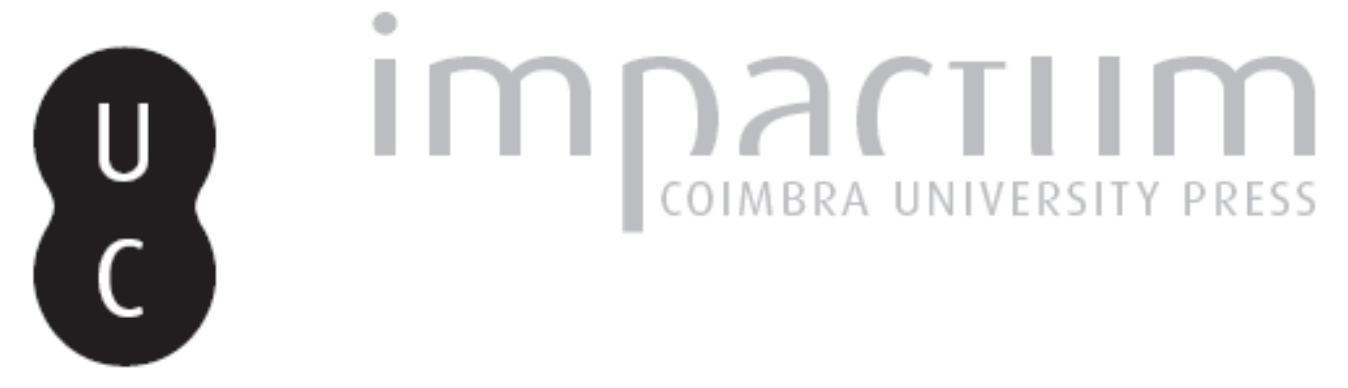

\title{
Caminhos de alteridade na Eneida e n'Os Lusíadas
}

Autor(es): $\quad$ Carvalho, Teresa Margarida Duarte

Publicado por: Faculdade de Letras da Universidade de Coimbra

URL persistente:

URI:http://hdl.handle.net/10316.2/39989

DOI:

DOI:https://doi.org/10.14195/0870-4112_2_21

Accessed : $\quad$ 26-Apr-2023 13:56:17

A navegação consulta e descarregamento dos títulos inseridos nas Bibliotecas Digitais UC Digitalis, UC Pombalina e UC Impactum, pressupõem a aceitação plena e sem reservas dos Termos e Condições de Uso destas Bibliotecas Digitais, disponíveis em https://digitalis.uc.pt/pt-pt/termos.

Conforme exposto nos referidos Termos e Condições de Uso, o descarregamento de títulos de acesso restrito requer uma licença válida de autorização devendo o utilizador aceder ao(s) documento(s) a partir de um endereço de IP da instituição detentora da supramencionada licença.

Ao utilizador é apenas permitido o descarregamento para uso pessoal, pelo que o emprego do(s) título(s) descarregado(s) para outro fim, designadamente comercial, carece de autorização do respetivo autor ou editor da obra.

Na medida em que todas as obras da UC Digitalis se encontram protegidas pelo Código do Direito de Autor e Direitos Conexos e demais legislação aplicável, toda a cópia, parcial ou total, deste documento, nos casos em que é legalmente admitida, deverá conter ou fazer-se acompanhar por este aviso. 
REVISTA DA FACULDADE DE LETRAS U N I VERS I A D E D E C O I M B RA 
O reflexo, ícone do mito de Narciso, constitui um elemento primordial para a compreensão do processo da identidade, revelando a necessidade do estabelecimento de uma relação com o Outro, que não um outro eu - revérbero insidioso à tona de água -, como processo funda mental para a construção do mundo.

A narrativa épica de Virgílio e $\boldsymbol{O}$ s Lusíadas, que nela bebem, pela temática da viagem, assumem-se como espaços privilegiados para a abordagem do Encontro com o Outro. E da viagem - expressão literária de todos os tempos e que, por isso, autoriza uma multiplicidade de diálo gos - sobressaem vozes e expressões, múltiplas e complexas, onde histó rico e mítico, temporal e eterno, profético e onírico, homens e deuses se cruzam.

O presente estudo, em viagem através da Eneida e de $\boldsymbol{O} \boldsymbol{s}$ Lusíadas, ruma, justamente, ao encontro com o outro, norteando-se por coordenadas e meridianos da filosofia de Emmanuel Levinas que tangem a problemática do encontro, do olhar e da comunicação, dimensões envolvidas no processo do conhecer e do reconhecer o outro e a si mesmo, sob a forma do eu ou do nós. Procurar-se-á traçar o perfil do herói, entidade de contornos imprecisos, cujos caracteres se enredam inextricavelmente na própria configuração da viagem e, consequente- *

* Este artigo constitui a versão reduzida de um trabalho elaborado no âmbito do seminário Matriz Latina das Literaturas Ocidentais, integrado no mestrado de Poética e Hermenêutica. Ao professor Doutor Carlos Ascenso André agradeço a orientação e a disponibilidade incondicionais, bem como as sugestões recebidas. 
mente, na sintagmática narrativa; nele confluem a experiência da partida, a ideia da (im)possibilidade do regresso ao lugar donde se parte, o desejo de procura do desconhecido, mas também a renovação, o crescimento espiritual e uma nova ordem social. A geografia, aqui retomada e ressemantizada, mais não é do que metáfora do sentido.

A problemática do outro é, em Levinas, uma novidade e um importante contributo para a filosofia contemporânea, apontando, simul taneamente, para uma crítica feroz à tradição filosófica ocidental, eivada de totalidade e de exclusão do outro e que desde sempre se apoiou no princípio da identidade ${ }^{1}$. Levinas contrapõe um novo paradigma - o da alteridade -, evidenciando que a presença do outro, que metaforiza na noção de Rosto, se concretiza exactamente na sua diferença em relação ao eu. Porém, o rosto apenas manifesta o vestígio da sua passagem, o mesmo é dizer, a "illeidade" manifesta-se no seu vestígio como algo que passa, parte e se dissolve ${ }^{2}{ }^{3}$. O outro é, então, diferença, estranheza, contrarie dade, infinitude. Pensador de uma alteridade irredutível, propõe uma ética da responsabilidade, do outro antes e acima do eu. Para este filósofo, o mundo ocidental está preenchido por «um imenso horror ao Outro». Nessa medida, ressalta do seu pensamento a inquietude diante da violên cia da negação do outro.

\section{PROJECTO}

\section{Da resposta profética ao compromisso com o Outro}

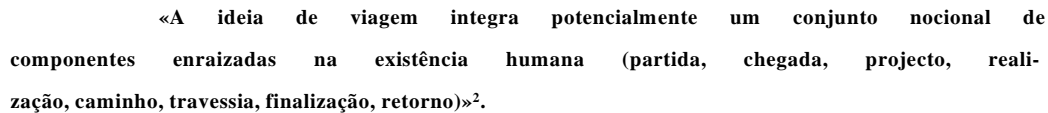

Levinas, numa tentativa de clarificar o conceito de alteridade, compara a História ocidental e o percurso da sua filosofia ao de Ulisses, «cuja aventura no mundo foi apenas um regresso à sua ilha natal - uma complacência no mesmo, um -desconhecimento do outro» ${ }^{4}$. De facto,

1 Cf. J. Vila-Chã, 'Emmanuel Levinas', Revista Portuguesa de Filosofia 47.1 (1991) 3: «Situar Levinas no contexto das transformações filosóficas do nosso século seria a forma mais adequada para introduzir a originalidade do seu pensamento.».

2 E. Levinas, Humanisme de FAutre Homme (Montpellier, Fata Morgana 1972) 60.

3 M. A. Seixo, Poéticas da Viagem na Literatura (Lisboa, Edições Cosmos 1998) 12.

4 E. Levinas, op. cit., 43.

\section{Faculdade de Letras I Universidade de Coimbra}


nesta perspectiva, a viagem de Ulisses revelar-se-á infrutífera: após ter regressado a ítaca, pode tornar a partir porque a ela tornará ciclicamente renovado. A este percurso, caracterizado pela recusa do compromisso com o outro e pela indiferença pela sua alteridade, pode contrapor-se o «humanismo do outro homem», que claramente prefere o paradigma da partida de Abraão ao do regresso do herói grego. A viagem de Ulisses, traduzindo um movimento de energia sempre igual a si mesma nas suas manifestações e técnica, ao contrário da de Eneias e da dos nautas portu gueses que, desenhando «um movimento para fora do idêntico» ${ }^{5}$, tendem para a abertura e para o outro, exprime bem a aceitação dos limites da vida e da condição humana. É a viagem, entendida como «movimento para um Outro» - o Infinito - 6 que oferecerá aos heróis de Homero e de Camões a imortalidade que Ulisses recusou quando Calipso lha prome tera, já que se apresenta como percurso de «sentido único», que a neces sidade de uma nova ordem social determina.

Propõe, assim, o filósofo um movimento, generoso e sem regresso, do mesmo ao outro - a obra, paciente, entendida como orienta ção absoluta para o outro interpelante.

(Re)clamados pelo destino -rosto velado e presença que inter pela-, os heróis de Virgílio e de Camões, na sua própria vez, respondem ao apelo do outro com aquela que é para Levinas a única e primeira res posta possível: "sim, eis-me aqui!"”, sem mesmo saber o que, concreta mente, deles se exige. Da resposta profética ressalta o elo entre o Eu e o Outro, só apertado na forma da responsabilidade, sem exigência de reci procidade, e a que o dito de Dostoievsky, na obra Os irmãos Karamasov, a que o filósofo alude, dá profundo sentido - «Somos todos culpados de tudo e de todos perante todos, e eu mais do que os outros».

Neste contexto, a noção de missão, à qual generosamente o Gama se entrega e que em Eneias se (con)funde com a própria missão de Roma, emerge, adquirindo especial relevância. A empresa que ambos têm em mãos e que forçosamente têm de levar a cabo ${ }^{8}$ - Encontro com o Futuro e com o Amor - colocá-los-á sob o desígnio da experiência,

5 Idem, p. 45.

6 Idem, Ética e Infinito (Lisboa, Edições 70 1988) 97-98: «Ninguém pode dizer em momento algum: cumpri todo o meu dever. Excepto o hipócrita...É neste sentido que há uma abertura para além do que se delimita; e tal é a manifestação do Infinito.».

7 Ibidem, 89.

8 Ibidem, 89: «Analiso a relação inter-humana como se, na proximidade com Outrem - para além da imagem que faço de outro homem -, o seu rosto, o expressivo no outro (e todo o corpo humano é, neste sentido, rosto), fosse aquilo que me manda servi-lo. Emprego esta fórmula extrema. O rosto pede-me e ordena-me.» 
entendida como provação. É a eleição para a vida: simultaneamente lágrima e hino de glória9 ${ }^{9}$.

A queda de Tróia faz assomar a figura de Eneias, escolhida para garante da fundação de Roma; o errante, viajante dos destinos, passa a ser explicitamente o plus - aquele que singularmente foi eleito pelos deuses. Esta sua nova condição, inalienável, actuará como promessa de vida e de futuro, dimensão que, porém, residirá esbatida pelo tempo que durar o sofrimento e a provação.

De modo semelhante, a história da gente lusa apresenta-se, aos olhos de Camões, como a progressiva realização do destino de um povo eleito $^{10}$. Assim, Vasco da Gama, respondendo incondicionalmente ao apelo desse destino, para além da própria posse, entrega-se ao outro sem retorno à vista. Contrariamente, Ulisses, guiado por um projecto indivi dual e egocêntrico, responde ao chamamento do seu próprio eu; a sua viagem terá como objectivo primeiro a busca do caminho que de novo o conduzirá a casa.

\section{APARTIDA}

\section{A saída de Si, por ordem de um mundo em desconcerto}

Tróia desmoronara-se. Confrontado com um cenário de ruína e de desolação, Eneias, subtraindo-se a um espaço de caos, parte irreconci liado com a condição humana. Agora, fato profugus, leva no olhar o fumo que se eleva da Tróia enrubescida. A ideia de viagem assoma, a de retorno não se vislumbra.

À semelhança de Ulisses, Eneias é um viajante mas sem pátria, sem Pénélope e sem esperança. É o viajante que carrega na bagagem a memória da destruição de Tróia. É um habitante angustiado de uma terra sempre distante, descentrado num universo feroz. À revelia da vontade, tem uma missão a cumprir - encontro com o futuro -, que aceita porque não pode deixar de o fazer. Eneias assume, assim, uma dupla sujeição: ao destino e ao velho pai que carrega nos ombros quando parte e que tomará como guia de viagem naquele que será um longo peregrinar.

Séculos mais tarde, e em circunstâncias diferentes (ou talvez não), ao encontro com o outro, partia a armada portuguesa, liderada pelo

\footnotetext{
9 Cf. Ibidem, 98: «O termo "glória" não pertence à linguagem da contemplação».

10 Vd. V. Aguiar e Silva, «Significado e estrutura de Os Lusíadas»; Separata do IV Centenário da Publicação de Os Lusíadas (Lisboa 1972) 14 e ss.
} 
Gama, também ele embarcado numa viagem que não escolhera, mas a que se oferece. Foge igualmente do caos - ordem quebrada de um mundo em desconcerto. Demanda o modelo do futuro, à semelhança de Eneias. A um e a outro, guia-os um superior destino - uma missão, o Infinito; a um e a outro, Júpiter profetiza fulgor, sediado no amor e no futuro - meios de ascese ao divino, numa palavra, alteridade, tal como Emmanuel Levinas a concebe.

\section{O CAMINHO}

\section{A obra paciente e generosa rumo ao Outro}

\section{Ao Encontro do Eu}

De um modo geral, a epopeia narra as dificuldades do percurso espinhoso de um herói, através das quais ele se afirma triunfalmente ${ }^{11}$. Exemplo emblemático é, pois, o de Ulisses - «o dos mil artifícios» aquele que, subtraindo-se sucessivamente à fúria dos elementos, supera todas as dificuldades graças ao seu engenho, que desce aos infernos e de lá regressa e que, por fim, impermeável ao outro, torna à sua Penélope. $\mathrm{Na}$ Eneida a figura de Ulisses está sempre implícita, por contraste, como se Virgílio usasse da semelhança para melhor significar a diferença. Eneias não é Ulisses.

Assim, sintomático é o encontro que Eneias tem marcado com o outro de si próprio e do qual dependem os destinos da futura Roma e de um império liberto de fronteiras espaciais e temporais. Ao contrário de Ulisses, que caminha no sentido do regresso, ou mesmo do Gama (já que a ideia de regresso fica implícita nas praias de Belém, embora ele se não cante), Eneias surge marcado pela nostalgia, senão mesmo pela doença de uma pátria a que não pode regressar.

Este decisivo Encontro com o outro - o herói do futuro - afi gura-se complexo pela natureza dilacerante do conflito que instaura: Eneias caminhará sempre ladeado pela raiz e pelo futuro. No predestinado herói fundador de Roma persiste teimosamente um eu, transbordante de passado, que aguarda, paciente, a morte. Ainda mal partira e já a saudade o devasta; o futuro, diluído e incerto, só vagamente ganha contornos para rapidamente se esfumar. É este apego ao eu do passado, é esta recusa a

${ }^{11}$ A. J. Saraiva, Luís de Camões (Lisboa, Edições Gradiva 1997) 121. 
um futuro que tem de conquistar mas que não lhe pertencerá, que o fará sofrer permanentemente ao longo do caminho até ao Lácio.

Se é verdade que o Gama se vê poupado a este conflito interior, porque renovado tem um eu a que regressa, vibra, no entanto, em todo o Poema, uma tensão interna resultante de uma dualidade contrastiva que nele procura conciliação: à exaltação da dignidade do Homem, pela divi nização da Humanidade, opõe-se a precariedade da natureza humana, a consciência, tantas vezes confessada, da sua fragilidade e da sua depen dência da «Divina Guarda». Estranhará, pois, o impaciente leitor da Eneida que Virgílio anuncie o canto de um «varão ilustre». Curiosamente, e quando o foco narrativo sobre ele incide, a primeira visão - ex abrupto - que o leitor tem desse mesmo varão é a de um náufrago que aporta a terras que não conhece, batido por ventos e vagas, chefe de uma frota desgovernada e dispersa e que, prostrado, afirma em atitude de prece:

$1.94-96$

'o terque quaterque beati

Quis ante ora patrum Troiae sub moenibus altis

Contigit oppetere! * $*$

«'O três e quatro vezes ditosos aqueles que, diante dos olhos dos seus pais, sob as altas muralhas de Tróia, a sorte concedeu que baqueassem!' ${ }^{\wedge}$

Ainda com um longo caminho a percorrer, este é o herói: o homem que em desespero deseja a morte, tal como o Gama que, apelando à «Divina Guarda», a desejará em circunstâncias semelhantes:

6. $83 \cdot 1-4$

Ó ditosos aqueles que puderam

Entre as agudas lanças africanas

Morrer, enquanto fortes sustiveram

A santa Fé, nas terras mauritanas; ^

O tópico do "herói acabrunhado" que perpassa n'Os Lusíadas é um legado da Eneida que, visando heroicizar uma pátria e um herói -

12 Virgile, Énéide. Texto fixado e traduzido por Jacques Perret (Paris, Les Belles Lettres 1978-1981). Todas as citações em latim se reportam a esta edição.

13 Tradução de Walter de Medeiros.

14 Camões, Os Lusíadas de Luís de Camões. Leitura, prefácio e notas de A. J. da Costa Pimpão. Apresentação de A. Pinto de Castro (Lisboa, Editorial do Ministério da Educação 1989). Todas as citações se reportam a esta edição.

\section{Faculdade de Letras | Universidade de Coimbra}


Roma, na sua missão civilizadora, e Eneias - simultaneamente os apre senta como anti-heróis, numa aparente derrogação dos códigos tradicio nais do p,oema épico. Todavia, é deste sentir de homens que desesperam, que parecem ter esgotado a força para continuar mas que persistem, que surgem esmagados por um destino que põe a nu a fragilidade duma heroi cidade que se não quis, que há-de nascer o herói. Assim, a chave do seu carácter, encontramo-la na obediência às exigências da empresa. É, pois, a viagem, entendida como um processo contínuo de descoberta, espaço simultaneamente geográfico e mítico, privilegiado para o encontro com o outro, que forjará o herói do futuro.

\section{No confronto do olhar}

Se, por um lado, desponta intrínseca a ideia de movimento como núcleo de sentido da viagem, por outro, a ideia de paragem também nela se inclui ${ }^{15}$. A paragem - caminho suspenso, também para o amor e para a guerra - ancoradouro tantas vezes não escolhido, afigura-se neces sária para contemplar ou apenas olhar, perscrutar, dialogar, questionar, apreender e... continuar.

Numa primeira instância, é o olhar - fronteira móvel e aberta para o mundo - o primeiro instrumento de avaliação crítica; assumindose, por um lado, como um meio de acesso ao outro e ao mundo, possibi lita, por outro lado, a construção do próprio eu. A caracterização de si mesmo aos olhos do outro - olhar reflectido - não pode, pois, ser descu rada. Porém, para que transcenda o visualmente apreensível (porque, ensina Levinas, o outro enquanto Outro escapa à fenomenologia do olhar), tem de transformar-se em elemento relacional cúmplice. Fixemos, pois, o olhar no primeiro encontro entre navegantes portugueses e nativos africanos.

Ao avistar Moçambique (1. 44) ao Gama «não lhe sucedeu como cuidava»: é a visão não procurada do outro - Encontro casual e incerto - onde o inesperado do novo, tão aterrador quão deslumbrante, faz com que as gentes, não se limitando ao papel do observador, se alvoro cem, exprimindo uma capacidade de emoção, pelo prazer do diverso ${ }^{16}$. $\mathrm{O}$ espanto e a curiosidade apoderam-se dos portugueses que não contêm as

15 M. A. Seixo, op. cit., 13.

16 M. L. C. Buescu, Os Lusíadas e o exotismo literário', Épica. Épicas. Épica camoniana (Lisboa, Cosmos 1997) 43. 
perguntas rituais: 'Que gente será esta? (em si diziam) /Que costumes, que Lei, que Rei teriam?' (1.45. ).

O exótico surge como motivo de admiração, emergindo um universo-outro, vivenciado dialecticamente, que conduz à aceitação do outro e legitima a alteridade, já que abre à aprendizagem do espaço onde ele se move, pelo empírico, o visual, o auditivo, numa palavra, o vivido. Camões coloca-nos diante dos olhos a experiência da percepção mútua. É a descoberta - efeito jubiloso da imagem de si mesmo desvelada no espelho do outro.

O «capitão sublime» recebe, acolhedor, a «gente estranha», mandando servir-lhe vinho. Interpelados pelos nativos de uma ilha insuspeitada, os portugueses dão «as discretas respostas que convinham», numa apresentação estratégica de si mesmo, onde, na apresentação tradi cional do viajante, se vislumbra a missão e a responsabilidade de a ver cumprida: Os portugueses somos do Ocidente, / Imos buscando as terras do Oriente.' (1.50.7-8). O Encontro exige, pois, a autodefinição, face à alteridade do outro. Eneias, quando aporta a terras estranhas e encontra uma bela deusa que o interroga, responde em moldes semelhantes:

1. $378-380$

'Sum pius Aeneas, raptos qui ex hoste Penatis

Classe ueho mecum, fama super aethera notus.

Italiam quaero patriam et genus ab love summo.'

«'Sou o pio Eneias, que trago comigo na armada os Penates arrebata dos aos inimigos, devido à fama conhecido até nos altos céus. Procuro a Itália, minha pátria, e reclamo descender do excelso Júpiter’.»^

Ainda a magia do olhar - do ver, do (re)ver-se e do ser visto assumindo-se, não raro, como ilusório refrigério, tantas vezes compro metendo o eu, e, simultaneamente, revelando-o.

Quando Eneias, envolvido numa nuvem, vê dirigidos os seus passos para as muralhas de Cartago, apresenta-se na posição de observa dor privilegiado - aquele que pode ver sem ser visto. A imagem do errante que acabara de sobreviver a um naufrágio, de futuro incerto, dominado por uma espécie de sentimento de vazio, contrasta sobrema neira com o quadro observado ${ }^{18}$. As muralhas de Cartago erguem-se 17 * Editora 2003) 23. 1964) 65 e ss.

17 Virgílio, Eneida. Coord, e notas de Luís M. G. Cerqueira (Lisboa, Bertrand

18 Vd. B. Otis, Virgil: a study in civilized poetry (Oxford, Oxford University Press

Faculdade de Letras i Universidade de Coimbra 
diante dos olhos de Eneias, como se o querer tivesse o poder mágico de trazer-lhe o destino já cumprido; é neles que perpassa a antevisão da futura Roma. Curiosamente, a primeira alusão a Cartago - cidade em construção - chega-nos pelo olhar distanciado de Eneias. O empenho, a solidez e a doçura marcam o labor conjunto dos Tirios e arrancam àquele que os contempla uma exclamação plena de significado:'O fortunati, quo rum iam moenia surgunt! - «Oh, afortunados, aqueles cujas muralhas se erguem já!'» (1.437). ${ }^{19}$

Eneias, ainda envolto em névoa que resguarda, introduz-se no meio destes homens, como querendo tomar parte de todo o bulício e de toda a prosperidade da cidade, no fundo, fundir-se no destino do outro, apaziguando o eu. O seu olhar, fixando-se, depois, no templo que a rainha dedicara a Juno, reclama a aparição do outro, antevendo-lhe a humani dade. É também o seu olhar, agora lacrimejante, pregado às paredes do templo, que lhe leva à memória o passado. Uma vez mais o passado. Revê, assim, na Ilion pintada, combates ordenados que celebram a histó ria de Tróia e um eu que a morte espreita.

Dissipada a nuvem, Eneias resplandeceu na claridade da luz, semelhante a um deus. É, pois, o momento da revelação, do encontro com o outro. Dido, também ela profuga, identifica-se com Eneias: similis for tuna, iactatam; a comiseração na desgraça - olhar reflectido - funciona como primeiro elemento de uma aproximação - sinal de abertura ao outro. Na óptica de Levinas, o olhar constitui apenas uma promessa de aproximação: «[...] diante do Rosto, Eu não posso ficar simplesmente a contemplá-lo, respondo-lhe» ${ }^{20}$. Assim, a resposta, aqui entendida como canto, é condição irredutível do encontro.

\section{O (en)Canto do Eu}

Cartago é a cidade escolhida para albergar a narração da queda de Tróia e a errância de Eneias. Melinde, a escolhida para albergar a narração das grandezas das gentes lusitanas. Uma e outra - portos de abrigo neste encontro com o outro - surgem marcadas pela ideia do acolhimento, que pressupõe mais o ouvir, atento e disponível, e menos o falar, que transforma quem é acolhido e, ao mesmo tempo, quem acolhe. A hospitalidade, enquanto experiência de abertura e de acolhimento, constitui o primeiro movimento em direcção ao compromisso, permitindo

19 Ed. L. M. G. Cerqueira, 24.

20 Levinas (1988) 80. 
passar do "eu sou", celebrado desde sempre pela tradição ocidental, para o «eis-me aqui», próprio da responsabilidade, como sublinha Levinas.

A rainha de Cartago recebe, em acto de hospitalidade, o outro que aporta às suas praias «de mãos vazias». Também o hospitaleiro rei de Melinde se desloca propositadamente às naus para escutar o canto do Gama. Assim, a noite de Cartago silencia-se para acolher o canto do guerreiro: à mesa do banquete, Conticuere omnes intentique ora tenebant - «todos se calaram e ficaram à escuta silenciosos» - (2. 1). De igual modo, prontos estavam todos escudando / o que o sublime Gama contaria (3. 3.1-2). Um e outro, conscientes da impossibilidade de abarcar no seu canto a totalidade, prometem o que não poderão cumprir: brevi dade. Por motivos diferentes, a um e a outro é comum a atitude que precede o acto de contar - um certo desconforto, o embaraço ao falar da pátria, que faz o Gama um pouco estar cuidando e Eneias afirmar da impossibilidade de conter as lágrimas. Dominado pelo aceso sentimento da perda, o sentido do canto de Eneias revela-se imediatamente como drama: 'Infandum, Regina, iubes renovare dolorem - «'Mandas-me, ó rainha, renovar uma dor infanda'» (2. 3) $)^{21}$. Ele não é apenas o herói que, pela contemplação do presente, ousa, pela primeira vez, sonhar o futuro, é também o homem vencido que chora o destino do seu povo. O seu canto, que é, afinal, o da ruína da sua pátria, faz surgir diante do outro que o escuta a tenebrosa noite troiana. Valia do canto, de quem teve nele boa parte, ou do seu génio criador, Tróia desmorona-se uma vez mais. Segue-se o canto da deambulação mediterrânica: a Trácia, Delos, Creta, Estrófades, Áccio, Sicília, Drépano e em lado nenhum Eneias pode ficar por não encontrar apaziguamento. E é em dor que termina.

Por seu lado, o canto do Gama surge marcado pelo tópico do encarecimento. Nele será tratada a «larga terra» e só depois a «sanguinosa guerra». Assim, o «capitão sublime» vai desfiando o rosário das glórias da gente lusa. Quando, por fim, termina a longa narração, Da boca do facundo capitão / Pendendo estavam todos, embebidos (5. 90.1-2) - é a magia do canto.

E porque o canto é vigília, também para quem escuta, decerto que o outro não terá deixado de notar que «a gente fortíssima», a «quem Marte obedeceu», nasceu de sucessivos «encontros temerosos» com o outro que veste, no canto do Gama, as cores do inimigo. Em quadros também eles sucessivos, terá perpassado, por certo, aos olhos do povo de Melinde, o encontro entre o «Principe Afonso» - objecto de uma atenção

21 Tradução de C. A. André.

\section{Faculdade de Letras I Universidade de Coimbra}


especialmente demorada - e o Divino (3. 42-54). «Com tal milagre» o luso inflama-se e «Rompe, corta, desfaz, abola e talha» (3. 51.8), assegu rando a vitória sobre o «Mouro atónito e torvado». O milagre de Ourique selava o encontro que colocou a espada ao serviço da Cruz. No gesto e nas lágrimas da «Fermosíssima Maria», implorando socorro «pelos pater nais paços sublimados», terá antevisto a gente de Melinde a gravidade do perigo do encontro entre o «Quarto Afonso» e o «Sarraceno bárbaro» (3. 107-117). É o encontro da consolidação do Cristianismo na Península, que confirmava o destino aceite e proclamado em Ourique. Decerto, o ouvido melindano também não terá ficado indiferente ao som da «trom beta Castelhana», sinal que anuncia, agora na nau do Gama, aquele que é o encontro nacional por excelência (4. 28-44): o «forte Dom Nuno Alva res» e o Castelhano defrontam-se entre o Artabro e o Guadiana. Este encontro, a princípio incerto, deixa o inimigo maldizendo e blasfemando / Do primeiro que guerra fez no mundo (4. 44.1-2)

Também para a rainha fenícia, já tomada de amores, o canto é de maravilhamento. Retida no fascínio do canto e naquele que o celebra, solicita insensatamente uma vez mais os trabalhos dos troianos, e de novo fica suspensa dos lábios do narrador... A rainha, na sua inconsciência trágica, é incapaz de vislumbrar o Eneias do futuro: entre a Tróia des truída e a Roma vislumbrada não cabem Dido ou a sua cidade. Esta ideia de suspensão, resultante do marcante encontro que acabara de viver, tra duz, de acordo com a filosofia levinasiana, o experienciar de um evento fora de medida, no sentido em que o eu, sísmicamente abalado, não con segue fazer face à vinda do outro, devido à ausência de um programa. Assim, o verdadeiro encontro mais não é que a experiência sísmica do outro. Daqui ressalta a ideia de revolução do eu: a paixão, que é em Dido, numa fase inicial, "ferida áfona", dando conta da ardência da dor do outro em si. Solicitado artificiosamente, o canto do guerreiro acabará por con verter-se em canto de paixão e morte. A ferida e a chama, associadas a este amor semeado pelos deuses, depressa alastram pelo Poema, assu mindo-se como elementos estruturantes da própria sintagmática narrativa e dizendo bem do desejo de Dido - a experiência da presença da ausência do outro em si. Levinas dá-nos também uma outra inspiração para pensar o desejo: não mais emergindo como uma falta, mas antes tendo como origem o outro, que o dita. Deste modo, o desejo, não se satisfazendo, alimenta-se da sua própria fome. ${ }^{22} \mathrm{Na}$ impossibilidade do outro, Dido vai-se consumindo assim. 


\section{O Forjar do Herói do Futuro}

Se o Encontro com o outro em Melinde acabará por transfor mar-se em sopro de vida para quem parte mas também para quem fica, já em Cartago o encontro reveste tons diversos.

A rainha fenícia surge envolvida numa aura trágica determi nada pela sua própria origem: ela é, desde o primeiro momento, uma rainha sacrificada à futura Roma, como o será Cleópatra. Virgílio sabia-o bem e, desde o início, concebe a sua heroína como a infelix Dido, fatal mente atraída por um amor que (pre)anunciará tragicamente a sua morte.

Neste encontro com o outro tem, aliás, a isotopía da caça fun ção estruturante, ao nível da sintagmática narrativa: o outro é a presa. Quando Eneias aporta a Cartago, a heroína magnífica - imagem cristali zada no símile de Diana - rapidamente se converte na corça ferida, reve lando uma situação outra: a sua nova condição. $O$ motivo da caça torna se, pois, um símbolo pressago, anunciando o inevitável: a tragédia havia começado; sentido bem diferente daquele que traduz, n'Os Lusíadas, o encontro amoroso entre nautas e ninfas que Pouco $\boldsymbol{e}$ pouco, sorrindo $\boldsymbol{e}$ gritos dando, /Se deixam ir dos galgos alcançando (9. 70.7-8).

Num afectuoso gesto de acolhimento do outro, Dido organiza uma caçada em sua homenagem. A bela Dido vai-lhe ao encontro em traje de caçadora. Eneias é o caçador Apolo. O ominoso símile é desvelado quando assistimos, sem rodeios, à consumação do amor na gruta. A condição do eu coloca nas suas mãos as armas que hão-de conduzir o outro à desgraça e o farão assumir, aos olhos deste, o papel do caçador cruel.

A tempestade que se abate depois da caçada, resultado do ardil coalescente de Vénus e Juno, não pode deixar de remeter-nos para aquela que se abatera inicialmente sobre Eneias. $E$ a presença do motivo báquico a marcar «aquele primeiro dia» da paixão consumada. Juno - o outro no plano divino - representando o elemento cartaginês do furor, empresta agora o seu traço ao amor de Dido que, entretanto, descura o seu povo e a sua cidade; Eneias, agora senhor de uma pátria que não fundou, esquecera a sua missão no regaço de Dido. O golpe de atrevimento faz voltar o deus, das lonjuras do Olimpo, para fazer relembrar ao Homem que dor e

\footnotetext{
comummente interpretado encontrar-se-ia a necessidade; o desejo marcaria um ser indigente e incompleto ou decaído da sua antiga grandeza. Coincidiria com a consciência do que foi perdido e seria essencialmente nostalgia e saudade. Mas desse modo nem sequer suspeitaria o que é o verdadeiramente outro.»
} 
verdade, inseparáveis, são pressuposto inderrogável da sua condição: Nauiget! (4. 237). O furor eleva-se no momento em que a Dido chegam as notícias dos preparativos da partida do guerreiro. Sentindo também o vigoroso sopro do destino, ela é, agora, a bacante louca que, tresloucada, deambula em fúria por toda a cidade. Não compreendendo a atenção e os cuidados excessivos dos deuses, Dido cresce como figura dramática;23 na sua atitude suplicante, multiplica argumentos, mas encontra tão só a fragilidade de um homem que sabe que tem de cumprir e não sabe como dizê-lo: Italiam non sponte sequor - «A Itália não é por minha vontade que a demando'.»(4.361) $)^{24}$. E, no confronto entre a raiz e o futuro, vê o leitor a impossibilidade de uma união na lágrima vã do herói.

Tentara em vão iludir o destino e aqui reside a sua culpa. No furor do amor rejeitado, ganha Dido contornos de Medeia:25 num sobres salto de defesa, encontra ainda novo alento para urdir a sua vingança; busca no suicídio o bálsamo que não encontrou no amor do Outro. A Fama de novo espalha a notícia: a perda de uma mulher superior e da sua obra. ${ }^{26} \mathrm{O}$ outro termina tragicamente instrumentalizado: «Voilà le fruit, voilà le résultat quand l'amour d'une femme est abusée pour des fins politiques.» ${ }^{27}$. Também assim para a linda Inês de Camões.

Dido e a sua doce cidade são para o incauto Eneias uma pince lada de vida breve e eufórica. O futuro sonhado, pela contemplação do presente, rapidamente se esfuma de forma dramática. Também em Cartago não pode ficar. Eneias aceita a provação do amor, revelando o heroísmo inerente ao seu próprio estatuto - o Princeps; recupera-se, assim, na obediência ao destino, e de novo volta a ser o pius - o escolhido para a obra da grandeza romana.

Diante dos olhos do leitor atento vai-se desenhando, pois, a impossibilidade de o peregrino ficar pelo caminho, não se cumprindo como herói. Os contornos da sua heroicidade apresentam-se ainda, com efeito, muito esbatidos, a esse carácter assiste ainda uma certa indefini ção, pelo que será necessário o herói afirmar-se com maior veemência. Assim é, também, para os nautas portugueses, que terão ainda de enfren-

23 P. S. Enk, 'La tragédie de Didorf, Latomus 16 (1957). O autor destaca a dramaticidade da figura de Dido: 637 «Le discours de Didon $n^{\prime}$ est pás une adaptation intérieure d'un modèle grec, mais une création originale de Virgile.»

24 Tradução de W. de Medeiros.

25 Para uma leitura da figura de Dido, nestes moldes, vd. A. M. Tupet, 'Didon magicienne', REL 48 (1970).

${ }^{26}$ P. S. Enk, art. cit., 632.

27 Ibidem, 640. 


\section{Teresa Margarida Duarte Carvalho}

tar na sua viagem um dos «filhos aspérrimos da Terra», guardião de um espaço sagrado.

O episodio do Adamastor sela, n’O.v Lusíadas, o primeiro encontro mítico, preparado com cuidados de Poeta, que abria, na história da «pequena casa lusitana» e da Humanidade, as portas de um mundo novo: «o novo mais novo que o novo», cintilando Infinito.

A princípio, o «monstro medonho» sobrepõe-se aos nautas, esmagando-os com a sua massa e o seu poder; depois, num processo de humanização progressiva - para o qual já muito se chamou a atenção - as posições invertem-se completamente. Com efeito, à significativa pergunta do Gama: «-Quem és tu?», responde o Gigante com a fragilidade suprema de figura trágica, esmagado pela adversidade e pela maldição de todo o amante desprezado. Os portugueses, agora conscientes do sentido que deve assumir a palavra Amor, afastam-se, apoderando-se de um lugar superior. O Outro, na sua dupla derrota, fica chorando.

Virgílio, por seu lado, não satisfeito ainda com a prestação do seu herói, coloca de novo no seu caminho a provação: fá-lo chegar a Cumas. Antes, porém, Eneias perderá Palinuro - o seu guia físico. É por seu meio que terá de prosseguir na estranha aventura que é a vida «car ce qui est demandé à l'homme en face du destin, c'est un effort de luci dité».28 Neste contexto, a descrição da morte e do Inferno ganha especial sentido na configuração da personalidade do herói.

$\mathrm{Na}$ viagem pelo mundo dos mortos - «o encontro com a morte e o passado para a preparação da vida e do futuro.» ${ }^{29}$ - atinge o herói o mais alto patamar do edificio épico. O leitor, por seu lado, é colocado no registo do sobrenatural. A natureza complexa do objecto da demanda - o futuro -, à semelhança da que se atesta em Camões - o amor - exige um processo de mediação: caminho ensinado àquele que, agora, viaja pelos infernos. É a Sibila a escolhida para o ofício de guia do herói no Além. Já os lusos, na Ilha dos Amores, terão como entidade mediadora as "esqui vas ninfas". Ainda assim, para que Eneias aceda ao mundo dos mortos e de lá regresse à luz, tem de penhorar o bem supremo. Miseno morrerá em sua vez - o preço pago pelo ramo de oiro - símbolo de luz nas trevas e de vida na morte. Aos indómitos portugueses nada de semelhante lhes foi exigido no decorrer da sua viagem em demanda da índia, porém, será com a própria vida que pagarão o golpe de atrevimento. Isso mesmo pro fetiza o Adamastor, fazendo eco das falas do Velho do Restelo à partida

28 Brisson, op. cit 290.

29 C. A. André, 'Morte e Vida na Eneida', in W. Medeiros et alii, A Eneida em contraluz (Coimbra, Instituto de Estudos Clássicos 1992) 58. 
de Lisboa: Naufrágios, perdições de toda sorte, /Que o menor mal de todos seja a morte! (5. 44.7-8).

Ganhar a Itália requer, ainda, do herói de Virgílio, um derra deiro esforço de lucidez. Encetará, pois, a viagem aos infernos como con dição - de agonia - que abrirá ao futuro e à alteridade. Deste modo, é a vida de Miseno que tomba, esvaída, para que a morte, estranhamente, alumie o caminhante. É o passado que sucumbe às mãos da nova vida que se impõe, ávida de futuro.

Logo à entrada do Orco - o encontro com a primeira provação, nova e inesperada - Eneias avista os males do mundo, entre eles a Guerra e a Discórdia, sublinhando de modo comedido o anseio de paz que per corre o poema. ${ }^{30} \mathrm{Na}$ mesma linha, Camões, aproveitando o encontro amoroso que há-de divinizar os portugueses, faz aparecer o amor «clara mente concebido como a força, ou o princípio, que corrige os desvios, erros e vícios perturbadores da lei que deve imperar no mundo» e cami nho efectivo para o outro. ${ }^{31}$

O herói de Virgílio caminha agora para um processo de conso lidação da alteridade que faz desta viagem uma experiência mística visando a integração cósmica. É o momento do encontro com o passado por ordem inversa. Começa por encontrar Palinuro que por ali deambu lava - o passado recente; nos campi lugentes encontra Dido - lívida - os que à sua semelhança morreram de amor, a consciência de um passado irrecuperável e, uma vez mais, a frustração; é em vão que evoca o motivo da sua partida apressada das praias de Cartago, a autoridade dos deuses, a missão...os fata: 'Inuitus, regina, tuo de litore cessi/- «foi contra von tade, rainha, que abandonei as praias do teu reino'» $(6.460)^{32}$.

Dido, completando o sentido trágico do livro IV, responde-lhe com o silêncio que fará de Eneias o herói da fragilidade suprema. E é o amor que sepulta por não ter onde albergá-lo. Encontrará, depois, guerrei ros gregos e troianos; singulariza-se o encontro com Deífobo: Tróia, do alto da sua grandeza, desmorona-se, agora, de modo irreversível. A des pedida de Deífobo ganha novo sentido: é o próprio herói, agora purifi cado, e pela primeira vez romano, que se despede do passado com o que ali termina.

30 M. H. da Rocha Pereira, Estudos de História da Cultura Clássica, Vol. II (Lisboa, Fundação Calouste Gulbenkian 1989) 281.

31 V. de Aguiar e Silva, 'O significado do Episódio da Ilha dos Amores na Estrutura de Os Lusíadas', Separata do XLVIII Curso de Férias da Faculdade de Letras da Universidade de Coimbra. Ciclo de Lições Comemorativas do IV Centenário da Publicação de Os Lusíadas (Coimbra 1972) 9.

32 Tradução de W. de Medeiros. 
A viagem prossegue, agora nos Campos Elisios. Quando encontra velho Anquises, o desejo do abraço tem o sentido da frustração eterno Fado (!) Mas é de futuro que o herói necessita. E é pela mão do velho pai que a ele acederá. Eneias, saído da «porta dos sonhos», e conhecedor do porvir, regressa à vida. Ele é, agora, o humano a quem os infernos deram contornos de herói renascido.

A descida aos Infernos do poema de Virgílio e o episódio camoniano da Ilha dos Amores parecem equivaler-se naquele que pode ser descrito como um gradual processo de ascese. $O$ cuidado posto na preparação do espaço parece ser sintomático da importância basilar que a ele se pretende atribuir na formação dos heróis do futuro. $\mathrm{Na}$ verdade é, respectivamente, no Inferno e na Ilha dos Amores, que Eneias - embora ainda de modo não definitivo -, e os portugueses encontrarão aquilo que realmente buscam: o verdadeiro outro - a alteridade que fará deles heróis. A acção concertada de Vénus e Júpiter (n'6fc Lusíadas como na Eneida) e a orientação da Sibila farão surgir os locais que hão-de transformar o mundo. Deste modo, a sua descrição é feita do geral para o particular, do exterior para o interior, num lógico processo de aproximação e de apro priação. O processo de transformação que os heróis irão viver pressupõe, em última análise, a capacidade de ad-propriare - viver e tomar próprio.

O herói virgiliano, orientado pela profetiza de Cumas, desce ao mundo dos mortos: o passado que carrega é progressivamente substituído pela revelação do futuro. Anquises, fundindo o mito e a história, profetiza os futuros heróis de Roma, destacando a figura de Augusto, prefigurada pelo próprio Eneias. Este, aprimorando-se como herói, encontra-se assim com o futuro, convertendo-se no romano. O Gama, recebendo Tétis por esposa, terá acesso ao futuro por meio da «Máquina do Mundo»: a con cretização do amor sublime, celebrado no ritual do casamento, propor ciona o discurso da gesta futura dos portugueses na (re)fundação e conso lidação de um Império. É a homenagem que a "senhora" das ninfas presta, assim, aos grandes vencedores e aos vindouros. O que tem lugar nos Campos Elisios sintetiza o que Virgílio aprendera em diversas escolas e parte, portanto, de uma cosmogonia de raiz estoica e da crença pitagó rica na metempsicose das almas, de influência visivelmente platónica. Camões, privado da utilização do poder demiúrgico, descreve, de modo criativo, a «Máquina do Mundo», assinalando, de acordo com o sistema geocêntrico de Ptolomeu, os pontos do globo onde actuarão os lusos. Numa perspectiva simbólica, os heróis, à margem do tempo, experien dam, em síntese, um processo que os habilitará a viver no mundo que lhes é desvelado. Ambos os processos se encontram ao serviço da glorifi 
cação da pátria e dos seus heróis. Do ponto de vista da economia da nar rativa, a prolepse revela-se eficaz nesse processo de glorificação, mas apenas pode figurar como desejo e profecia.

Por outro lado, a «Ilha Namorada» apresenta uma notável ana logia com os Campos Elisios, como local de bem-aventurança; talvez por isso, na descrição destes espaços, o elemento luz - factor de nobilitação esteja tão presente. A fresca ilha móvel é propositadamente colocada no caminho dos fatigados marinheiros como recompensa final de uma dura jornada. É o momento celebrativo da consagração suprema de «uma gera ção que há-de enfim instaurar uma nova ordem, servindo de paradigma ao mundo vil enredado nas malhas do desconcerto».33 Contrariamente, a descida de Eneias ao Além é ainda uma manifestação da pietas do herói, apesar de a interioridade do herói do futuro, à saída dos infernos, ser pro posta como modelo imitável.

Eneias já teve o seu prémio, breve e fugaz, quando a mesma deusa, sua mãe, o fez retemperar forças no conforto do regaço feminino. O grau de espiritualidade em Virgílio contrasta sobremaneira com o ero tismo desinibido do episódio camoniano. Por fim, entre o desfecho de um e de outro "episódios" parece poder estabelecer-se um paralelo que se funda numa ilusão criada. Virgílio faz sair Eneias e a Sibila pela «porta de marfim» - a porta dos "sonhos falsos", levando o leitor a duvidar da rea lidade narrada. N'6Lv Lusíadas, Camões parece negar tudo quanto ali se passou quando explicita que a «Ilha angélica pintada» Outra cousa não é que as deleitosas /Honras que a vida fazem sublimada (9. 89.3-4) .

A Ilha - Paraíso perdido, agora recuperado - simboliza a vitó ria de todos quantos, por sua conduta virtuosa e seus méritos, dela se tor naram dignos. Ela é o prémio da vitória humana, do Eu de cada um, onde as fronteiras se definem no Infinito, aquele de que nos fala Levinas. O Amor - humano, mítico, vitorioso - assume, pois, uma importância capi tal na arquitectura do Poema: é o fio mágico que permite aceder ao outro, o guia mítico e futuro do homem português e universal.

Os lusíadas, agora apropriados do espírito divino, embarcam para aquela que deverá ser uma nova pátria.

\section{0 Encontro (com)prometido}

Na Eneida, Virgílio, esquadrinhador da alma humana, continua a exigir do seu herói: fá-lo prosseguir na demanda de uma nova pátria.

33 Aguiar e Silva (1972) 12. 
Deste modo, Eneias tem ainda de palmilhar o duro caminho da guerra, memória sangrenta, ainda tão presente, que lhe devolve a amargura da derrota e a consciência do perecível; porém, é este o caminho que o levará ao futuro, em tudo diferente do que Dido lhe propusera em Cartago. O encontro mítico com o outro multifacetado - Latino, Amata, Turno - vaise esboçando assim, antevendo-se especialmente complexo.

Chegado à Itália, é a paz que procura, em vão; o povo de Latino escolhe a guerra e as armas ressoam: é a descrição da carnificina, onde as vidas ceifadas dizem do valor guerreiro do herói. Aqui, o encon

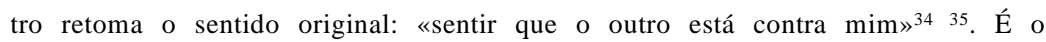
choque de olhares hostis que se cruzam negando a alteridade humana. É a visão da existência, reduzida a um ou outro pormenor. Eneias insiste na ideia da paz; é, aliás, isso mesmo que afirma ao inimigo quando este lhe pede tréguas para sepultar os seus mortos. Da impossibilidade da paz nasce, nas palavras de Eneias, a ideia do combate singular:

\section{1. $115-118$}

'Aequius huic Turnum fuerat de opponere morti.

Si bellum finire manu, si pellere Teucros

Apparat, his mecum decuit concurrere telis;

Uixet, cui uitam deus aut sua dextra dedisset.,

«'Fora mais justo que Turno se expusesse a esta morte. Se ele se pre

para para terminar a guerra pelo combate e expulsar os Teucros, deveria ter com batido comigo com estas armas'» ${ }^{33}$

Este combate iminente - encontro brutal - delineia-se, aos olhos do leitor sensível, em tons de cinza e preto, assumindo contornos de injustiça: o duelo pela posse da Terra Prometida e pela mão de Lavinia, desejada por Turno mas prometida a Eneias, tem, desde há muito, um vencedor que se esbaterá, porém, nas cores desmaiadas da sua vitória.

O outro aproxima-se, assustadoramente, da metáfora de que se serve Levinas para o expressar. Turno, estrangeiro na sua própria pátria, para a qual tinha um projecto, na sua nudez e miséria humanas, mani festa-se como rosto auto-expressivo, impondo-se para além da forma plástica $^{36}$. A assimetria da relação eu/outro - estruturante da filosofia levinasiana - diz bem da figura do herói maldito: ela situa-se num plano

34 P. L. Entrai go, Teoria y Realidad del Otro (Madrid 1983) 373.

35 Ed. L. M. G. Cerqueira, 215.

36 F. Bernardo, 'O rosto como Expressão: ou o acolhimento do outro/outro segundo E. Levinas', Revista Filosófica de Coimbra 7, n 13 (1998); vd. especialmente 109 e ss. 
mais elevado, é mais que o eu de Eneias na sua presença apelativa; tendo na relação a primazia, ela é já a própria palavra: «a epifania do rosto, por sob a qual a alteridade e a exterioridade do outro se "apresentam" na sua vulnerabilidade, inaugura a primeira palavra»37. «"Tu não matarás" é a primeira palavra do rosto» ${ }^{38} 39$. Eneias, todavia, indiferente à atenção que o outro lhe solicita, não ouve o seu apelo:

\section{2. $936-938$}

' Vicisti et uictum tendere palmas

Ausonii videre; tua est Lauinia coniux.

Vlterius ne tende odiis.,

«'Venceste, e 0 vencido os Ausónios o viram a

suplicantes. Lavinia é tua esposa. Não leves mais longe o teu ódio'».30

Num passo dado sob o signo da irreversibilidade, desfere Eneias o golpe fatal que rouba ao outro a graça da vida, mas não a possi bilidade da transcendência infinita do seu ser - expressão original «mais forte que o homicida» ${ }^{40}$. Também assim para aqueles que com Eneias fizeram caminho ou com cuja vida se cruzaram.

Se Os Lusíadas «são um canto de luz, que nitidamente triunfa das sombras»41, e a Eneida um canto de negrume e de morte, talvez isto se deva ao caminho que cada um dos seus heróis tem de trilhar para alcançar o objecto da sua busca: alteridade. A catábase virgiliana e o epi sódio da «Ilha dos amores», constituindo viagens a sub-mundos que res pondem ao apelo lançado pelo outro, traduzem bem a diferença entre os dois poemas. Todavia, aproxima-os uma espécie de linha de futuro que, concorrendo com o passado, os atravessa e os transcende.

De facto, a epopeia de Virgílio e a de Camões em muito pare cem reflectir a filosofia levinasiana - a ética como filosofia primeira - 42

37 Ibidem, 105.

38 Levinas (1988), op. cit., 80.

39 Tradução de C. A. André.

40 E. Levinas, Le Temps et L'Autre (Paris, Fata Morgana 1979) 59: «L'adage antique destiné à dessiper la crainte de la mort : Si tu es, elle n'est pas ; si elle est, tu n'es pas, - méconnaît sans doute tout le paradoxe de la mort, puisque'il efface notre relation avec la mort qui est une relation unique avec l'avenir.».

41 C. A. André, ‘A Dimensão Visual da Épica Camoniana', IV Reunião Internacional de Camonistas: actas (Ponta Delgada 1984) 63.

42 Levinas propõe para a filosofia uma nova orientação: a ética não é mais o saber do bem fazer, traduzindo um programa normativo de um registo do campo filosófico, mas 
pela constelação de valores em que se movem. A ideia de futuro expressa em Virgílio, com tudo o para o poeta ela significava - paz alicerçada na justiça, lealdade, clemência ${ }^{43}$ - e o amor, largamente expresso em Camões, são apresentados como valores a que o Homem de todos os tem pos aspira e pelos quais tende a bater-se. Mais do que Roma e Portugal, o que assoma é a ideia da refundação da Humanidade, na qual o Homem, artífice da sua própria vitória, tem um papel crucial. Neste contexto, é o perigar da identidade que conduz à alteridade. Assim, em vez de cerrar, a derrota final de Eneias abre um sentido novo: a morte faz falta à vida.

É este o significado profundo que faz com que seja, afinal, pos sível que a estranha sobrevivência das grandes obras se deva ao facto de terem nascido num presente - uma espécie de tempo sem tempo - no qual os Homens podem criar obras atemporais, com que transcendem a sua própria finitude.

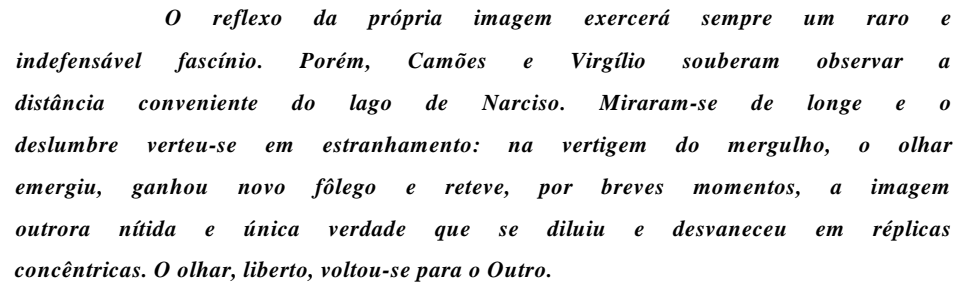

antes relação incondicional ao Outro. A tese central da obra Totalidade e Infinito - a ética como filosofia primeira - induziu Lévinas à crítica frontal da categoria totalidade, celebrada desde sempre pela filosofia ocidental nesse seu culto do Mesmo, do pensamento absoluto e globalizador. Por outro lado, o filósofo nela destaca o face a face humano como sendo a fonte de todo o sentido.

Vd. M. H. da R. Pereira, 'Virgílio, poeta da paz e da missão de Roma', Estudos em homenagem a Jorge Borges de Macedo (Lisboa, Centro de Arqueologia e História da Universidade de Lisboa 1992) 73-85.

Faculdade de Letras | Universidade de Coimbra 